\title{
Pengaruh Efikasi Diri terhadap Prestasi Belajar Siswa Kelas XI IPS pada Mata Pelajaran Ekonomi di SMAN 7 Kerinci
}

\author{
Ermannudin \\ Guru SMAN 7 Kerinci \\ Correspondence email: ermannudinman@gmail.com
}

\begin{abstract}
Abstrak. Penenlitian ini bertujuan untuk mengetahui pengaruh efikasi diri terhadap prestasi belajar siswa kelas XI IPS pada mata pelajaran ekonomi di SMA Negeri 7 Kerinci. Penelitian ini menggunakan metode penelitian kuantitatif dengan pendekatan ex post facto. Populasi yang digunakan dalam penelitian ini adalah siswa kelas XI IPS di SMA 7 Kerinci sebanyak dua kelas, dimana penulis memberikan pembelajaran pada mata pelajaran ekonomi di kelas tersebut berjumlah 48 siswa. Sampel dari penelitian ini adalah populasi itu sendiri berjumlah 48 siswa. Instrumen dalam penelitian ini menggunakan angket berbentuk pernyataan dengan skala liket sebagai pengukuranya untuk mengukur variable efikasi diri (X) dan untuk mengukur prestasi belajar dapat dilihat dari hasil belajar mata pelajaran ekonomi semester genap tahun ajar 2020/2021. Perhitungan data dengan menggunakan analisis regresi linier sederhana dengan melihat pengaruhnya melalui uji t. Ada beberapa tahapan-tahapan sebelum uji tersebut dilakukan seperti uji validitas, uji homogenitas, dan uji asumsi klasik (uji normalitas dan uji homogenitas). Hasil dari penelitian ini adalah variabel efikasi diri (X) memiliki pengaruh positif terhadap prestasi belajar (Y) siswa kelas XI IPS di SMA Negeri 7 Kerinci dengan melihat hasil perhitungan Nilai t hitung diperoleh sebesar 2,285 $>$ dari t tabel sebesar 2.011 atau taraf signifikansi sebesar $0,034<0,05$ yang berarti Ho ditolak dan Ha diterima. Pengaruh efikasi diri terhadap prestasi belajar tergolong cukup kuat yaitu sebesar $42,3 \%$ dan sisanya diperngaruhi variabel bebas yang lainnya sebesar $57,7 \%$. Semakin tinggi efikasi diri yang dipunyai siswa akan membawa pengaruh yang tinggi juga prestasi belajar siswa pada mata pelajaran ekonomi dan sebaliknya apabila efikasi diri yang dipunyai siswa rendah maka akan membawa pengaruh yang rendah juga prestasi belajar pada mata pelajaran ekonomi.
\end{abstract}

Kata Kunci: Efikasi Diri, Prestasi Belajar

\begin{abstract}
This study aims to determine the effect of self-efficacy on the learning achievement of students in class XI IPS on economics subjects at SMA Negeri 7 Kerinci. This study uses quantitative research methods with an ex post facto approach. The population used in this study were students of class XI IPS at SMA 7 Kerinci as many as two classes, where the author gave lessons on economic subjects in that class totaling 48 students. The sample of this study was the population itself amounted to 48 students. The instrument in this study uses a questionnaire in the form of a statement with a Liket scale as a measurement to measure the self-efficacy variable $(X)$ and to measure learning achievement can be seen from the learning outcomes of economic subjects in the even semester of the 2020/2021 academic year. Calculation of data using simple linear regression analysis by looking at the effect through the t test. There are several stages before the test is carried out such as validity test, homogeneity test, and classical assumption test (normality test and homogeneity test). The results of this study are the self-efficacy variable $(X)$ has a positive influence on learning achievement (Y) of class XI IPS students at SMA Negeri 7 Kerinci by looking at the calculation results. $0.034<0.05$, which means $H o$ is rejected and Ha is accepted. The effect of self-efficacy on learning achievement is quite strong, namely $42.3 \%$ and the rest is influenced by other independent variables of $57.7 \%$. The higher the selfefficacy of the students, the higher the influence of the students' learning achievement in economic subjects and vice versa if the self-efficacy of the students is low, it will have a low influence on learning achievement in economics subjects.
\end{abstract}

Key words: Self-Efficacy, Learning Achievement

\section{PENDAHULUAN}

Perkembangan IPTEK saat ini semakin menjadi suatu kebutuhan, terlebih lagi saat musim pandemic covid-19 penggunaan teknologi amat sangat membantu aktivitas kehidupan manusia, dimana dalam melakukan aktivitasnya manusia dilakukan dari rumah karena manusia harus menjaga jarak dari manusia lain demi keselamatan umat manusia juga. Penguasaan IPTEk bagi manusia menuntut setiap manusia mengembangkan dan membentuk sumber daya manusia (SDM) yang berkualitas. Untuk menciptakan sumber daya manusia yang berkualitas dengan melakukan proses pendidikan, dimana manusia harus dapat menyesuaikan dengan ilmu pengetahuan dan teknologi sehingga dapat memenuhi tuntutan pendidikan. Oleh 
Ermannudin, Pengaruh Efikasi Diri terhadap Prestasi Belajar Siswa Kelas XI IPS pada Mata Pelajaran Ekonomi di SMAN 7 Kerinci

karena itu, demi mencapai tuntutan pendidikan diperlukan sumber daya manusia yang kapabilitas, professional, siap bersaing dan memiliki mobilitas yang tinggi dalam berpikir dan bertindak, serta berahlakulkarimah, sehingga dapat berperan aktif dalam membangun bangsa dan negara ini.

Apabila negara ingin mempersiapkan sumber daya manusia yang sesuai dari pada fungsi dan tujuan pendiidikan nasional yang tertuang dalam pasal 3 Undang-undang no 20 tahun 2003 yaitu "Pendidikan nasional berfungsi mengembangkan kemampuan dan membentuk watak serta peradaban bangsa yang bermartabat dalam rangka mencerdaskan kehidupan bangsa, bertujuan untuk berkembangnya potensi siswa agar menjadi manusia beriman dan bertakwa kepada Tuhan Yang Maha Esa, berahlak mulia, sehat, berilmu, cakap, kreatif, mandiri, dan menjadi warga negara yang demokratis serta bertanggung jawab". Dari fungsi dan tujuan pendidikan tersebut, maka salah satu caranya adalah dengan memberikan bekal pendidikan bagi generasi penerus bangsa dengan menanamkan pemahaman tentang ilmu pengetahuan agama dan ilmu pengetahuan dan teknologi yang disesuaikan berdasarkan kurikulum yang berlaku.

Saat ini, dunia pendidikan kita tengah disoroti sebagai salah satu sector dalam mewujudkan Indonesia maju yang belum berhasil mengembangkan misi dan visi dari pendidikan itu sendiri dalam mencerdaskan kehidupan bangsa. Salah satu contohnya banyak perilaku yang menyimpang dari masyarakat menjadi bukti bahwa dunia pendidikan kita belum mampu menjadi solusi dari pengembangan misi dan visi pendidikan tersebut. Hal ini terjadi karena adanya kaitan erat dengan proses belajar yang dialami setiap individu atau siswa dalam jenjang pendidikan yang dilaluinya. Oleh karena itu hendaknya dunia pendidikan kita mulai berbenah untuk memperbaiki system pendidikan kea rah yang lebih baik dengan perlahan tapi pasti jangan menjadikan pendidikan sebagai kelinci percobaan untuk mengeluarkan kebijakan yang hanya menguntungkan kepentingan beberapa pihak. Mulailah berbenah dengan saling bekerjasama antar steacholder yang berkecimpung di dunia pendidikan demi generasi anak cucu sebagai penerus bangsa.

Memasuki era globalisasi dan digitalisasi, pendidikan sebagai bagian integral kehidupan masyarakat seyogyanya memberi dan memfasilitasi bagi tumbuh dan berkembangnya keterampilan intelektual, sosial dan personal. Pendidikan harus dapat mampu menumbuhkan berbagai kompetensi siswa yang sering dikenal dengan sebutan "four C (4C)" diantaranya critical thinking, creativity, communication skill, dan Ability to work collaboratelly. Keempat kompetensi siswa tersebut akan mampu membuat siswa agar memiliki keterampilan intelektual, sosial, dan personal yang dibangun bukan hanya dengan landasan rasio dan logika saja, tetapi juga inspirasi, kreativitas, moral, intuisi (emosi), dan spiritual (Kagan, 1994), seperti apa yang termaktub dalam UU Republik Indonesia No. 20 Tahun 2003 tentang pengertian pendidikan, dimana pendidikan merupakan suatu usaha sadar dan terencana untuk mewujudkan suasana belajar dan proses pembelajaran agar siswa secara aktif mengembangkan potensi dirinya untuk memiliki kekuatan spiritual keagamaan, pengendalian diri, kepribadian, kecerdasan, akhlak mulia, serta keterampilan yang diperlukan dirinya, masyarakat, bangsa, dan negara. Sebuah institusi berlangsungnya proses pendidikan salah satunya adalah sekolah, karena sekolah dianggap sebagai miniature dari masyarakat sehingga perlu dikembangkan suatu proses pembelajaran sesuai dengan tuntutan era globalisasi dan digitalisasi. Hal ini sejalan dengan teori konstruktivisme yang dikemukakan Smith et.al (2010), dimana teori tersebut menyatakan bahwa pembelajaran merupakan proses untuk mengkontruksi pengetahuan, bukan untuk menduplikasi pengetahuan.

Pengetahuan dikonstruksi berdasarkan keaslianya tidak hanya artifisialnya, sehingga mendorong terciptanya makna belajar yang sesungguhnya bagi siswa. Seperti penelitian yang ditemukan Fathhulkhoir (2015) bahwa pada kenyataanya banyak siswa belajar hanya mampu dalam menyajikan tingkat hafalan yang baik pada suatu materi ajar yang diperolehnya, namun siswa tersebut tidak memahami makna dari materi yang telah diperolehnya. Padahal, belajar tidak hanya sebatas pada proses menghafal saja, melainkan siswa juga dituntut untuk memilki keterikatan dengan apa yang dipelajarinnya. Untuk itu perlunya efikasi diri dalam belajar, karena efikasi diri itu muncul dari pengalaman keberhasilan yang dilakukan siswa dalam melakukan suatu tugas yang sifatnya kontinyu dan di dalamnya memungkinkan siswa untuk belajar dari tugas yang dilakukan (mastery experiences). Selain itu, efikasi juga terbentuk dari mekanisme pemodelan atau percontohan; memandang keberhasilan siswa lain dalam suatu tugas (vicarious experiences), persuasi 
Ermannudin, Pengaruh Efikasi Diri terhadap Prestasi Belajar Siswa Kelas XI IPS pada Mata Pelajaran Ekonomi di SMAN 7 Kerinci

verbal dan sosial (verbal and social persuasion), serta kondisi raga dan jiwa dari siswa itu sendiri (physiological and emotional states).

Adapun dalam konteks pengembangan sumber daya manusia yang berkualitas, seharusnya sekolah dalam hal ini melakukan kegiatan pengembangan dan pelatihan guna menumbuhkan efikasi diri pada siswa. Hal ini dikarenakan, efikasi diri bukanlah suatu sifat yang melekat pada seseorang atau diri siswa itu sendiri, melainkan lebih kepada kecenderungan perilaku (behavior) siswa. Efikasi diri tersebut memungkinkan untuk diubah, diperkuat serta ditingkatkan. Siswa dengan efikasi diri tinggi secara mental dan perilaku menunjukkan kesiapan yang lebih baik dalam mengerjakan tugas dan melakukan aktivitas pembelajaran dibandingkan dengan siswa yang mempunyai efikasi diri rendah. Indikasi adanya kematangan efikasi diri pada siswa dapat dilihat dari ketekunan, ulet, tidak mudah putus asa, tidak mudah menyerah, tidak gampang stres ketika mengalami kegagalan, serta berupaya untuk meningkatkan standar kinerja. Secara konseptual, efikasi diri dibagi atas efikasi diri spesifik (specific self-efficacy) dan efikasi diri umum (general selfefficacy). Pada prinsipnya efikasi diri merupakan pengembangan atau modifikasi dari efikasi diri spesifik (specific self-efficacy) yang sekarang ini banyak digunakan di berbagai bidang seperti: kesehatan, manajemen, kepemimpinan, pendidikan, sosial, dan disiplin ilmu lainnya.

Fakta dilapangan tentang pendidikan di negara kita ini bahwa dalam proses belajar mengajar nampaknya harus merekonstruksi internal para siswa. Perilaku menyontek (cheating) yang dilakukan para siswa merupakan suatu fenomena pendidikan yang sering terjadi dan bahkan selalu muncul menyertai aktivitas proses belajar mengajar. Perilaku menyontek (cheating) merupakan suatu perbuatan yang dilakukan siswa dengan cara ilegal atau curang untuk tujuan dalam menyelesaikan tugas akademik terutama yang berkaitan dengan evaluasi atau ujian hasil belajar. Hal inilah yang menjadi salah satu indikasi bahwa para siswa belum mampu untuk mencapai kemandirian dalam proses belajar. Para siswa yang terbiasa menyontek akan senang menggantungkan pencapaian hasil belajarnya pada orang lain atau sarana tertentu dan bukan pada kemampuan dirinya sendiri secara tidak terhormat, yang bertujuan memperoleh suatu keberhasilan. Dengan ini, siswa banyak mengalami penurunan dalam hal semangat belajar. Karena banyak siswa yang meremehkan sistem pendidikan. Kasus ketidakjujuran dalam pendidikan dikalangan siswa sering muncul menyertai aktivitas belajar mengajar tetapi jarang menjadi pembahasan dalam wacana pendidikan Indonesia.

Pada sebuah studi menyebutkan bahwa lebih dari $50 \%$ sampai dengan $80 \%$ para siswa dilaporkan pernah menyontek. Minimnya pembahasan tentang permasalahan kasus menyontek ini dikarenakan bahwa kebanyakan orang menganggap kasus ini merupakan hal yang sepele, dan wajar saja terjadi di kalangan siswa, serta tidak membahayakan siswa dikarenakan tidak mengandung unsur kekerasan (violence). Namun, dampaknya sangat besar bagi siswa diantaranya memuncul sikap mental yang malas, mempunyai dorongan belajar yang rendah mereka akan terbiasa melakukan kecurangan untuk mencapai hasil yang mereka harapkan, sehingga siswa tidak mempunyai efikasi diri terhadap diri sendiri, maka mengakibatkan siswa bertindak curang dengan menyotek. Idealnya, apabila seseorang mendapatkan kesempatan untuk belajar di sekolah yang cukup tingi yaitu pendidikan SMA maka seseorang tersebut dituntut untuk melakukan tindakan yang lebih dari mereka yang masih mengenyam pendidikan di SMP atau SD. Bagi siswa yang berkesempatan mengenaym pendidikan SMA dalam belajar di sekolah hendaknya dituntut untuk bukan hanya memiliki keterampilan teknis tetapi juga memiliki motivasi belajar yang kuat agar mampu mencapai keyakinan (selfefficacy) yang baik dan dapat mecapai hasil belajar yang diharapkan atau diinginkan melebihi standar nilai KKM. Hal tersebut mengarah pada siswa dituntut untuk memiliki efikasi yang tinggi agar tujuan dari proses pembelajaran bisa tercapai. Seperti yang dikemukakan Ghufron dan Risnawita (2011) yang menyatakan bahwa efikasi diri merupakan salah satu aspek atau unsur pengetahuan tentang diri atau self-knowledge yang amat penting pengaruhnya dalam menjalankan kehidupan manusia sehari-hari. Hal ini disebabkan efikasi diri yang dimiliki ikut mempengaruhi individu dalam menentukan tindakan yang akan dilakukan untuk mencapai suatu tujuan, termasuk didalamnya perkiraan berbagai kejadian yang akan dihadapi.

Berdasarkan uraian permasalahan secara umum tentang efikasi diri yang terjadi di lingkup dunia pendidikan, maka peneliti tertarik untuk mengkaji efikasi diri siswa di SMAN 7 Kerinci yang mana sekolah 
Ermannudin, Pengaruh Efikasi Diri terhadap Prestasi Belajar Siswa Kelas XI IPS pada Mata Pelajaran Ekonomi di SMAN 7 Kerinci

tersebut merupakan salah satu tempat pendidikan dimana penulis ditugaskan untuk mengajar khususnya untuk siswa kelas XI IPS pada mata pelajaran yang saya ampu yakni mata pelajaran ekonomi. Selama pengamatan proses belajar mengajar pada mata pelajaran ekonomi tahun ajaran 2020/2021 banyak ditemukan permaslahan dari mulai melakukan pembelajaran samapi ujian akhir semester diantaranya masih banyak para siswa mengganggap remeh mata pelajaran ekonomi karena mereka menganggap mata pelajaran tersebut banyak materi teori dibandingan dengan materi hitungan, bila diberikan tugas hampir seleruh siswa menjawab sama persis atau saling mencontek antara siswa yang satu dengan siswa yang lain, siswa yang asyik sendiri seperti melamun, bicara dengan teman, atau menjahili teman yang lain ketika guru sedang menerangkan dikelas atau bahkan tak banyak siswa yang mengerjakan tugas harian dikarenakan kurangnya pemahaman pada soal, dan menganggap remeh UAS (Ulangan Akhir Semester) karena para siswa merasa yakin jika mereka akan naik kelas sehingga tak sedikit ditemukan para siswa banyak yang menyontek hal ini merupakan salah satu penyebab para siswa tidak termotivasi siswa dalam belajar.

Permasalahan di atas jelas menunjukan bahwa para siswa mempunyai motivasi yang rendah, selain fakta tersebut juga masih ditemukan fenomena lain yang menambah runtutan permasalahan tentang efikasi diri pada kelas XI IPS di SMAN 7 Kerinci sesuai dengan hasil wawancara dengan guru BK dalam menangani problematika para siswa yang mayoritas berasal dari kelas IPS ditemukan bahwa dalam proses belajar-mengajar juga ditemukan siswa sering membolos dan tidak menaati tata tertib disekolah. SMAN 7 Kerinci merupakan salah satu tempat sekolah pendidikan formal yang memiliki tingkat akreditasi yang baik. Sekolah ini memiliki tujuan untuk menciptakan siswa yang memilki daya saing, dan berahlak seperti tujuan dari pendidikan nasional. Sehingga dalam sekolah ini siswa diharapkan dapat memiliki tingkat kualitas prestasi belajar yang tinggi. Sekolah ini memiliki program yang baik dalam rangka memajukan kualitas dan kuantitas sumber daya manusia tertama pada siswa atau guru-guru yang ada didalamnya. Langkah yang dilakukan sekolah ini untuk memajukan kulitas dan kuantitas sumber daya manusianya, maka sekolah akan memberikan penghargaan atas hasil yang dicapai baik dalam ulangan, ujian maupun tugastugas lainnya berupa nilai, hadiah atau pujian, agar dapat menumbuhkan persaingan kompetitif yang positif melalui penetapan ranking, menetapkan hukuman atas kesalahan yang dilakukan siswa, menumbuhkan hasrat belajar, menumbuhkan minat, dan mengarahkan tujuan yang akan dicapai para siswa. Adapun tujuan dilakukan penelitian ini adalah untuk mengetahui pengaruh efikasi diri dengan prestasi belajar siswa kelas XI IPS pada mata pelajaran ekonomi di SMA Negeri 7 Kerinci.

\section{LANDASAN TEORI}

\section{Efikasi Diri}

Social Cognitive Theory yang dikemukakan oleh Bandura (1997) merupakan cikal bakal munculnya teori efikasi diri (self-eficacy). Dimana, menurutnya self efficacy merupakan keyakinan seseorang terhadap kemampuan yang dimiliki untuk mengontrol fungsi diri dan lingkungannya. Selain itu juga, menurt Feist \& Feist (2009) self efficacy merupakan faktor dari perubahan kognitif pada remaja, kemampuan seseorang untuk menampilkan tindakan-tindakan dari level yang ditunjukkan untuk menentukan bagaimana orangorang merasakan, berpikir, memotivasi dirinya dan berperilaku. Seorang siswa dalam menyelesaikan permasalahan, maupun dalam proses penyesuaian diri ketika dalam posisi banyak permasalahaan, memerlukan suatu keyakinan terhadap kemampuan diri sendiri karena hal tersebut akan menentukan tindakan yang dilakukan dan hasil yang ditunjukkan (Artha\& Supriadi, 2013). Lain halnya pendapat yang dikemukakan Ormrod (2008) yang menyatakan bahwa self- efficacy merupakan bagian peneliaian individu akan kemampuan yang ada dalam dirinya, dan kemampuan itu berguna untuk menjalankan sesuatu dengan mencapai tujuan tertentu.

Efikasi diri mengacu pada keyakinan sejauhmana seseorang atau individu memprediksi kemampuan dirinya dalam melaksanakan tugas atau melakukan suatu aktivitas yang diperlukan untuk mencapai suatu hasil tertentu (Bandura dalam Mawanti, 2011). Keyakinan yang dimaksud adalah seluruh kemampuan yang dimiliki meliputi kepercayaan diri, kapasitas kognitif, kemampuan menyesuaikan diri, kecerdasan, kapasitas bertindak pada situasi yang penuh tekanan dan permasalahan. Lebih lanjut Bandura dan Wood (Pinasti, 2011) menyatakan bahwa self efficacy is "belief in one's capabilities to mobilize the motivation, cognitive 
Ermannudin, Pengaruh Efikasi Diri terhadap Prestasi Belajar Siswa Kelas XI IPS pada Mata Pelajaran Ekonomi di SMAN 7 Kerinci

resources, and courses of action neede to meet given situational demand". Definisi tersebut memiliki makna bahwa kemampuan seseorang atau individu dalam hal ini adalah siswa untuk menggerakkan motivasi, sumber-sumber kognitif, dan serangkaian perlakuan yang yang dibutuhkan untuk memenuhi tuntutantuntutan dari situasi yang dihadapi.

Sementara itu, terdapat makna lain dalam kehidupan sehari-hari tetang efikasi diri yaitu kemampuan mengarahkan kepada sekumpulan target yang menantang dan tidak pantang menyerah dalam mendapatkannya (Myers, 2012). Friedman dan Schustack (2006) menyatakan bahwa "Self-efficacy is an expectation-belief (hope) about how far an individual is able to perform a behavior in a certain situation". Definisi tersebut mengisyaratkan bahwa efikasi diri sebagai bentuk ekspektasi dari keyakinan seseorang dalam menaruh harapan tentang sejauh mana seseorang tersebut melakukan suatu tindakan dalam situasi tertentu. Masih merujuk pendapat Bandura (Hidayat, 2015) menyatakan bahawa efikasi diri sebagai penilaian terhadap kemampuannya yang dimiliki yang berg6na untuk mengatur dan menjalankan kinerja yang sudah ditetapkan. Efikasi diri ini memberikan dasar bagi motivasi siswa, kesejahteraan dan prestasi perserta didik itu sendiri. Mereka meyakini prilaku yang mereka lakukan akan mendapatkan hasil sesuai dengan yang diinginkan, meskipin ada terdapat sedikit intensif atau untuk bertahan dalam menghadapi persoalan atau kesulitan.

Selain dari definisi tentang efikasi diri yang telah dipaparkan sebelumnya, tentunya ada beberapa factor-faktor yang mempengaruhi tentang efikasi diri seperti apa yang tengah dikemukakan Ormrod (2008) diantaranya 1) keberhasilan dan kegagalan dari belajar sebelumnya; 2) pesan yang disampaikan dari orang lain; 3) Melihat kesuksesan dan kegagalan dari orang lain; 4) Melihat kesuksesan dan kegagalan dari sekelpompok orang yang lebih banyak. Ghufron dan Rini Risnawati (2011) ada beberapa factor yang mempengaruhi e adalah fikasi diri diantaranya 1) Pengalaman Keberhasilan (mastery experience); 2.) Pengalaman orang lain (vicarious experience); 3) Persuasi Verbal; dan 4) Kondisi fisiologis. Adapun factor -faktor lain yang mempengaruhi efikasi diri yang dikemukakan oleh Bandura (Mawanti, 2014) antara lain: 1) Sifat tugas yang dihadapi, 2) Insentif eksternal berupa hadiah (reward), 3) Status atau peran individu dalam lingkungan, dan 4) Informasi tentang kemampuan diri.

Menurut Bandura (Bastable, 2002) Self efficay secara kognitif dinilai dan diproses melalui empat sumber informasi terpenting: (1) penyelesaian kinerja yang tampak dalam penguasaan diri perilaku yang diharapkan, (2) pengalaman yang seolah dialami sendiri seperti mengobservasi keberhasilan perilaku yang diharapkan dengan cara mencontoh orang lain, (3) persuaisi verbal oleh orang lain yang memperlihatkan keyakinan realistis bahwa seseorang sanggup dalam hal perilaku yang diharapkan, dan (4) perangsang emosi melalui penilaian sendiri atas kondisi fisiologis yang menyusahkan. Indikator dari efikasi diri menurut Smith et.al (2010) mengacu pada tiga dimensi yakni level, strength, dan generality. Ketiga dimensi tersebut, memunculkan beberapa indicator dalam pengukuran tentang efikasi diri yakni 1) meyakini dapat melakukan tugas tertentu, yang mana siswa memiliki keyakinan melakukan tugas dan target apa yang harus diselesaikan; 2) menyakini dapat memotivasi diri untuk melakukan tindakan dalam menyelesaikan tugas; 3) menyakini bahwa siswa mampu berusaha dengan keras, gigih, dan tekun dalam menyelesaikan tugas dengan segala sesuatu yang dimilikinya; 4) meyakini bahwa dirinya mampu menghadapi hambatan dan rintangan dalam menyelesaikan tugas dan bangkit dari kegagalan; dan 5) meyakini dapat menyelesaikan permasalahaan dalam situasi dan kondisi apapun.

\section{Prestasi Belajar}

Prestasi berasal dari bahasa Belanda yaitu "Prestatie" kemudian disadur kedalam bahasa Indonesia menjadi prestasi yang memiliki arti hasil usaha. Sedangkan Belajar memiliki arti suatu aktivitas di mana terdapat sebuah proses dari tidak tahu menjadi tahu, tidak mengerti menjadi mengerti, tidak bisa menjadi bisa untuk mencapai hasil yang optimal (Ihsana, 2017). Dalam dunia pendidikan penilaian atau ukuran untuk melihat perkembangan dan kemajuan siswa yang berkenaan dengan penguasaan pelajaran yang disiapkan untuk siswa serta nilai-nilai yang terdapat dalam kurikulum bisa disebut dengan prestasi belajar. Adapun definisi prestasi belajar menurut Maesaroh (2013) menerangkan bahwa "prestasi belajar 
Ermannudin, Pengaruh Efikasi Diri terhadap Prestasi Belajar Siswa Kelas XI IPS pada Mata Pelajaran Ekonomi di SMAN 7 Kerinci

merupakanyaitu suatu hasil daripada aktivitas belajar atau hasil dari usaha, latihan dan pengalaman yanag dilakukan oleh siswa, dimana prestasi tersebut tidak akan lepas dari pengaruh faktor luar diri siswa.

Lebih lanjut Winkel (Pratiwi, 2015) mendefinisikan prestasi belajar sebagai bukti dari keberhasilan yang telah dicapai individu, dengan demikian prestasi belajar dapat dikatakan sebagai suatu hasil maksimum yang dicapai oleh individu setelah melaksanakan berbagai usaha dengan cara belajar. Prestasi belajar dapat dinyatakan dalam bentuk simbol, angka, huruf, ataupun kalimat sebagai cerminan dari hasil yang sudah dicapai oleh setiap siswa dalam periode tertentu dan dapat dinyatakan bahwa prestasi belajar merupakan hasil dari suatu kegiatan pembelajaran yang disertai perubahan yang dicapai siswa (Rosyid, Zaiful dan Aminol, 2019). Djamarah (2012) menyatakan bahwa prestasi belajar adalah hasil yang didapat berupa kesan-kesan yang menyebabkan perubahan dalam diri siswa sebagai hasil dari kegiatan dalam belajarnya. Sedangkan Susanti (2019) mendefinisikan prestasi belajar sebagai suatu kemampuan dalam menyelesaikan hal sulit, menguasai, mengungguli, menandingi, dan melampaui siswa lain sekaligus mengatasi hambatan dan mencapai standar yang tinggi.

Untuk mengetahui pencapaian prestasi belajar yang telah dicapai siswa, maka dilaksanakanlah evaluasi pembelajaran. Tujuan evaluasi tersebut adalah untuk mengetahui keefektifan dan keberhasilan proses belajar mengajar sehingga dalam pelaksanaannya evaluasi harus dilakukan secara terus-menerus. Evaluasi itu sendiri dilakukan untuk mengetahui prestasi belajar siswa yang diperoleh selama mengikuti pembelajaran. Prestasi belajar yang diperoleh siswa memiliki banyak factor seperti yang diungkapkan Mulyasa (dalam Istirani dan Intan, 2017) yang dapat dikelompokkan menjadi empat, yaitu : 1) Bahan atau materi yang dipelajari, 2) Lingkungan, 3) Faktor instrumental, dan 4) Kondisi siswa

Ada beberapa factor-faktor yang mempengaruhi prestasi belajar siswa yang dikemukakan oleh Slameto (2015) diantaranya 1) Faktor internal yaitu faktor yang ada dalam diri individu yang sedang belajar, antara lain: faktor jasmaniah (kesehatan dan cacat tubuh), faktor psikologis (intelegensi, perhatian, minat, bakat, motif, kematangan, kesiapan), dan faktor kelelahan. 2) Faktor eksternal yaitu faktor yang ada di luar individu, antara lain: faktor keluarga (cara orang tua mendidik, relasi antar anggota keluarga, suasana rumah, keadaan ekonomi keluarga, pengertian orang tua, latar belakang kebudayaan), faktor sekolah (metode mengajar, kurikulum, relasi guru dengan siswa, relasi siswa dengan siswa, Disiplin sekolah, alat pelajaran, waktu sekolah, standar pelajaran di atas ukuran, keadaan gedung, metode belajar, tugas rumah), dan faktor masyarakat (kegiatan siswa dalam masyarakat, teman bergaul, dan bentuk kehidupan masyarakat).

Selain factor-faktor prestasi belajar yang telah dipaparkan sebelumnya, pada dasarnya prestasi belajar memiliki beberapa fungsi seperti yang diungkapkan oleh Arifin (2011) diantaranya yaitu 1) Indikator kualitas dan kuantitas pengetahuan yang telah dikuasai siswa; 2) Lambang pemuasan hasrat ingin tahu., 3) Bahan informasi dalam inovasi pendidikan; 4) Indikator intern dan ekstern dari suatu institusi pendidikan, dan 5) indikator terhadap daya serap anak didik. Pentingnya mengetahui prestasi belajar siswa untuk melihat sejauh mana siswa mempelajari dan memahami proses belajar yang dilakukanya baik individual maupun kelompok karena prestasi belajar tidak hanya seabagai indikator keberhasilan, dan juga berguna bagi guru yang bersangkutan serta sebagai umpan balik dalam melaksanakan pembelajaran di kelas apakah akan diadakan remedial dalam proses belajar mengajar ataupun tidak.

Untuk mengetahui kemampuan dari prestasi belajar siswa diperlukan beberapa indicator untuk mengukurnya seperti yang diungkapkan oleh Syah ( 2017) yaitu 1) Ranah Kongnitif, maksudnya prestasi belajar seseorang bisa dilihat dari pengamatannya, ingatannya, pemehaman, aplikasi, analisis dan sintesis. 2) Ranah Afektif, maksudnya prestasi belajar seseorang bisa dilihat dari peneriman, sambutan, apresepsi (sikap menghargai), internalisasi (pendalaman), dan karekteristik (penghayatan). 3) Ranah Psikomotor, maksudnya prestasi belajar seseorang dapat dilihat dari keterampilan bergerak dan bertindak serta kecakapan ekspresi verbal dan nonverbal. Sehingga, dapat disimpulkan bahwa untuk mengukur prestasi belajar dengan menggunakan indicator ranah kognitif, ranah afektif dan ranah psikomotor. Ketiga ranah sebagai indikator tersebut tidak dapat dipisahkan satu dengan yang lain, untuk mewujudkan prestasi yang baik. Tipe hasil belajar kognitif lebih dominan daripada afektif dan psikomotor karena lebih menonjol, namun hasil belajar psikomotor dan afektif juga harus menjadi bagian dari hasil penelitian dalam proses pembelajaran. 


\section{METODE PENELITIAN}

Metode penelitian yang digunakan dalam penulisan ini dalah metode penelitian kuantitatif dengan pendekatan ex post facto. Menurut Riduwan (2012) penelitian ex post facto merupakan suatu penelitian yang dilakukan untuk meneliti peristiwa yang telah terjadi dan kemudian melihat ke belakang untuk mengetahui faktor-faktor yang dapat menimbulkan kejadian tersebut. Terdapat dua variable dalam penelitian ini yaitu variable bebas yakni efikasi diri (X) dan variable terikat yakni Prestasi Belajar (Y). Populasi yang digunakan dalam penelitian ini adalah siswa kelas XI IPS di SMA 7 Kerinci sebanyak 2 kelas, dimana penulis memberikan pembelajaran pada mata pelajaran ekonomi di kelas tersebut dapat diketahui jumlah siswa pada tabel berikut:

Tabel 1

Populasi Penelitian

\begin{tabular}{|l|l|c|}
\hline No & \multicolumn{1}{|c|}{ Siswa Kelas } & Jumlah \\
\hline 1 & XII IPS 1 & 25 \\
\hline 2 & XII IPS 2 & 23 \\
\hline & Jumlah & $\mathbf{4 8}$ \\
\hline
\end{tabular}

Menurut Arikunto (2017) populasi merupakan keseluruhan dari subjek penelitian atau suatu wilayah yang digeneralisasikan terdiri atas objek/subjek yang mempunyai kuantitas dan karakteristik tertentu yang diterapkan oleh peneliti untuk dipelajari dan kemudian ditarik kesimpulannya. Dari tabel di atas diketahui bahwa jumlah populasi dalam penelitian ini sebanyak 48 siswa. Masih menurut Arikunto (2017) apabila jumlah popuasi tersebut kurang dari 100 maka yang dijadikan sampel dalam penelitian adalah populasi itu sendiri. Berdasarkan pernyataan tersebut, maka penulis menggunakan sampel penelitian sebanyak 48 siswa.

Instrumen dalam penelitian ini menggunakan angket berbentuk pernyataan dengan skala liket sebagai pengukuranya untuk mengukur variable efikasi diri (X) dan untuk mengukur prestasi belajar dapat dilihat dari hasil belajar mata pelajaran ekonomi semester genap tahun ajar 2020/2021. Stelah angket disebarkan kepada sampel penelitian sebanyak 30 siswa sebagai uji coba dan dikumpulkan kembali, langkah selanjutnya adalah melakukan uji validitas dan reliabilitas dari angket tersebut. Apabila angket tersebut dinyatakan valid dan reliable maka langkah selanjutnya melakukan penelitian dan pentabulasian data untuk menghitung pengaruh atau tidaknya efikasi diri terhadap prestasi belajar siswa kelas XI IPS di SMAN 7 Kerinci. Setelah dilakukan pentabulasian data langkah selanjutnya melakukan uji analisis deskriptif, uji asumsi klasik yakni uji normalitas dan uji homogenitas, dan uji regresi linier sederhana guna menganalisis hipotesa penelitian dengan menggunakan uji t. Penulis menggunakan bantuan program komputer SPSS for Windows versi 25 dalam melakukan perhitungan data dengan berpedoman pada panduan Gozali (2018).

\section{HASIL DAN PEMBAHASAN}

Dari hasil pengamatan penulis situasi belajar kelas XI IPS di SMA Negeri 7 Kerinci dengan lingkungan sekolah yang cukup nyaman dan tenang karena jauh dari pusat keramaian sehingga sangat mendukung kelancaran proses belajar mengajar dan didukung pula oleh sarana dan prasarana yang ada di sekolah seperti perpustakaan, laboratorium komputer, laboratorium MIPA, perpustakaan, dan ruang UKS. Kegiatan belajar mengajar pada masa pandemic covid 19 ini dibagi beberapa ship pertemuan, ada yang dilakukan tatap muka dalam proses pembelajaran dan ada juga proses pembelajaranya dilakukan secara daring. Dari data yang diambil langsung dilapangan bahwa sarana dan prasarana yang ada di SMA Negeri 7 Kerinci tergolong lengkap dan masuk kedalam kondisi baik. Sarana dan prasarana yang ada dapat digunakan oleh guru dan siswa yang berada di SMA Negeri 7 Kerinci. Sarana dan prasara yang ada di SMA Negeri 7 Kerinci ini mampu mendukung segala aspek kegiatan yang ada di SMA Negeri 7 Kerinci, tidak hanya dapat mendukung kegiatan akademik saja, sarana dan prasarana yang tersedia juga mampu mendukung kegiatan non-akademik. 
Ermannudin, Pengaruh Efikasi Diri terhadap Prestasi Belajar Siswa Kelas XI IPS pada Mata Pelajaran Ekonomi di SMAN 7 Kerinci

Adanya fasilitas yang dimilki sekolah sangat memadai tentunya para siswa bisa dikatakan nyaman dalam belajar. Dari penyebaran angket yang dilakukan sebagai uji coba untuk menghitung uji validitas dan reliabilitas data demi keabsahan penelitian yang dilakukan, dimana hasil uji tersebut sebanyak 20 varian pernyataan tentang variable efikasi diri dapat dilihat pada tabel berikut:

Tabel 2

Uji Validitas

Item-Total Statistics

\begin{tabular}{|c|c|c|c|c|}
\hline & $\begin{array}{c}\text { Scale Mean } \\
\text { if Item } \\
\text { Deleted }\end{array}$ & $\begin{array}{c}\text { Scale } \\
\text { Variance if } \\
\text { Item Deleted }\end{array}$ & $\begin{array}{l}\text { Corrected } \\
\text { Item-Total } \\
\text { Correlation } \\
\end{array}$ & $\begin{array}{c}\text { Cronbach's } \\
\text { Alpha if Item } \\
\text { Deleted }\end{array}$ \\
\hline $\begin{array}{l}\text { VAR0000 } \\
1\end{array}$ & 69.03 & 82.171 & .530 & .890 \\
\hline $\begin{array}{l}\text { VAR0000 } \\
2\end{array}$ & 68.83 & 81.661 & .526 & .890 \\
\hline $\begin{array}{l}\text { VAR0000 } \\
3\end{array}$ & 69.00 & 78.621 & .686 & .886 \\
\hline $\begin{array}{l}\text { VAR0000 } \\
4\end{array}$ & 68.93 & 79.099 & .566 & .888 \\
\hline $\begin{array}{l}\text { VAR0000 } \\
5\end{array}$ & 69.03 & 76.792 & .684 & .885 \\
\hline $\begin{array}{l}\text { VAR0000 } \\
6\end{array}$ & 69.07 & 79.099 & .633 & .887 \\
\hline $\begin{array}{l}\text { VAR0000 } \\
7\end{array}$ & 69.17 & 74.213 & .827 & .880 \\
\hline $\begin{array}{l}\text { VAR0000 } \\
8\end{array}$ & 69.13 & 76.395 & .752 & .883 \\
\hline $\begin{array}{l}\text { VAR0000 } \\
9\end{array}$ & 69.23 & 73.840 & .780 & .881 \\
\hline $\begin{array}{l}\text { VAR0001 } \\
0\end{array}$ & 69.10 & 76.231 & .720 & .883 \\
\hline $\begin{array}{l}\text { VAR0001 } \\
1\end{array}$ & 69.10 & 75.817 & .675 & .884 \\
\hline $\begin{array}{l}\text { VAR0001 } \\
2\end{array}$ & 69.27 & 79.444 & .439 & .892 \\
\hline $\begin{array}{l}\text { VAR0001 } \\
3\end{array}$ & 68.33 & 79.126 & .404 & .894 \\
\hline $\begin{array}{l}\text { VAR0001 } \\
4\end{array}$ & 68.77 & 81.978 & .400 & .903 \\
\hline $\begin{array}{l}\text { VAR0001 } \\
5\end{array}$ & 69.10 & 80.093 & .469 & .891 \\
\hline $\begin{array}{l}\text { VAR0001 } \\
6\end{array}$ & 69.10 & 83.197 & .461 & .896 \\
\hline
\end{tabular}


Ermannudin, Pengaruh Efikasi Diri terhadap Prestasi Belajar Siswa Kelas XI IPS pada Mata Pelajaran Ekonomi di SMAN 7 Kerinci

\begin{tabular}{|l|r|r|r|r|} 
VAR0001 & 69.07 & 81.789 & .371 & .893 \\
VAR0001 & 68.93 & 80.892 & .503 & .890 \\
8 & & & & \\
VAR0001 & 69.00 & 82.483 & .382 & .894 \\
9 & & & & \\
VAR0002 & 68.83 & 79.868 & .387 & .897 \\
0 & & & & \\
\hline
\end{tabular}

Tabel uji validitas tersebut mengindikasikan bahwa varian pertanyaan variabiel efikasi diri (X) yang dituangkan kedalam angket dan disebarkan sebagai uji coba dinyatakan valid karena hasil perhitunganya dari masing-masing varian pertanyaan menunjukan $r$ hitung $>r$ tabel $(0,361)$ dengan sampel uji coba 30 siswa. Sedangkan hasil uji reliabilitas dapat disajikan melalui tabel berikut:

\section{Tabel 3 \\ Uji Reliabilitas}

\begin{tabular}{|} 
Reliability Statistics \\
\begin{tabular}{|r|r|}
\hline $\begin{array}{c}\text { Cronbach's } \\
\text { Alpha }\end{array}$ & N of Items \\
\hline .894 & 20 \\
\hline
\end{tabular}
\end{tabular}

Tabel Reliabelitas tersebut mengindikasikan bahwa variable efikasi diri (X) dinyatakan reliable karena $r$ hitung sebesar $0.894>r$ tabel $(0,361)$ dengan sampel uji coba 30 siswa. Setalah dilakukan uji validitas dan uji reliabilitas, maka langkah selanjutnya dilakukan penelitian kembali dengan menyebarkan angket kepada 48 siswa yang menjadi sampel dalam penelitian ini dan dari angket tersebut dikumpulkan kembali kemudian dilakukan pentabulasian data untuk melakukan tahapan perhitungan selanjutnya. Adapun perhitungan selanjutnya adalah menghitung uji analisis deskriptif yang dapat disajikan pada tabel berikut:

\section{Tabel 4}

\section{Uji Analisis Deskriptif}

\section{Descriptive Statistics}

\begin{tabular}{|l|r|r|r|r|r|}
\hline & \multicolumn{1}{|c|}{$\mathrm{N}$} & $\begin{array}{c}\text { Minimu } \\
\mathrm{m}\end{array}$ & $\begin{array}{c}\text { Maximu } \\
\mathrm{m}\end{array}$ & \multicolumn{1}{c|}{ Mean } & \multicolumn{1}{c|}{$\begin{array}{c}\text { Std. } \\
\text { Deviation }\end{array}$} \\
\hline Efikasi Diri (X) & 48 & 56 & 94 & 79.85 & 10.470 \\
Prestasi Belajar & 48 & 65 & 95 & 78.17 & 6.914 \\
$(\mathrm{Y})$ & 48 & & & & \\
Valid N (listwise) & & & & \\
\hline
\end{tabular}

Hasil uji analisis deskriptif pada tabel di atas dapat diketahui bahwa masing-masing variable bebas dan variable terikat memilki karakteristik nilai yang berbeda beda. Untuk variable efikasi diri (X) memiliki nilai maksimum sebesar 94 dan nilai minimum 56. Rrata-rata dari variable efikasi diri (X) sebesar 79,85 dan standar deviasi sebesar 10.470 dari jumlah data sampel sebanyak 48 siswa. Sedangkan untuk variabel prestasi belajar (Y) nilai maksimum diperoleh sebesar 95 dan nilai minimum 65. Rrata-rata dari variable prestasi belajar (Y) sebesar 78,17 dan standar deviasi sebesar 6.914 dari jumlah data sampel sebanyak 48 
Ermannudin, Pengaruh Efikasi Diri terhadap Prestasi Belajar Siswa Kelas XI IPS pada Mata Pelajaran Ekonomi di SMAN 7 Kerinci

siswa. Langkah perhitungan selanjutnya adalah dengan melakukan uji asumsi klasik yaitu normalitas dan homogenitas. Adapun perhitungan uji normalitas dapat dilihat pada tabel berikut:

\section{Tabel 5 \\ Uji Normalitas}

One-Sample Kolmogorov-Smirnov Test

\begin{tabular}{|ll|r|r|}
\hline & & $\begin{array}{r}\text { Efikasi } \\
\text { Diri (X) }\end{array}$ & $\begin{array}{c}\text { Prestasi } \\
\text { Belajar } \\
(\mathrm{Y})\end{array}$ \\
\hline $\mathrm{N}$ & & 48 & 48 \\
Normal Parameters ${ }^{\mathrm{a}, \mathrm{b}}$ & Mean & 79.85 & 78.17 \\
& Std. & 10.470 & 6.914 \\
& Deviation & .127 & .089 \\
Most Extreme & Absolute & .088 & .088 \\
Differences & Positive & -.127 & -.089 \\
& Negative & .127 & .089 \\
Test Statistic & & $.151^{\mathrm{c}}$ & $.200^{\mathrm{c}, \mathrm{d}}$ \\
\hline Asymp. Sig. (2-tailed) & &
\end{tabular}
a. Test distribution is Normal.
b. Calculated from data.
c. Lilliefors Significance Correction.
d. This is a lower bound of the true significance.

Hasil uji normalitas yang disajjikan pada tabel di atas menunjukan bahwa data tersebut berdistribusi normal. Hal ini bisa dilihat dari nilai Asymp. Sig. (2-tailed) dari variable efikasi diri (X) sebesar 0,151 > taraf signifikansi 5\% atau 0,05, sehingga dapat disimpulkan bahwa data tersebut adalah normal. Demikian juga untuk data prestasi belajar (Y) dimana nilai Asymp. Sig. (2-tailed) diperoleh sebesar 0,200 > taraf signifikansi 5\% atau 0,05 maka dapat dikatakan juga data tersebut juga normal. Masing-masing variabel efikasi diri (X) dan prestasi belajar (Y) dinyatakan normal maka akan dilakukan uji asumsi klasik selanjutnya yaitu uji homogenitas dengan menggunakan uji Levene Statistic untuk mengetahui variasi kelompok populasi homogeny atau tidak dapat disajikan pada tabel berikut:

\section{Tabel 6 \\ Uji Homogenitas}

Test of Homogeneity of Variances

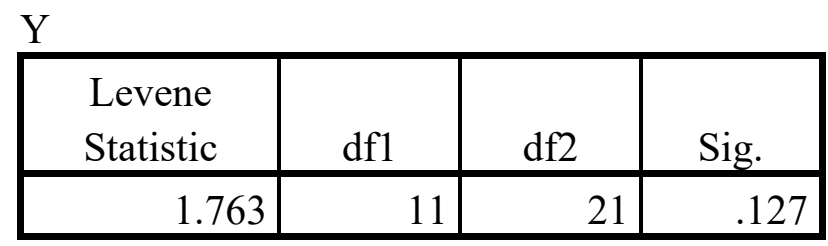

Uji Levene Statistic yang hasilnya dapat dilihat pada tabel di atas adalah untuk mengetahui homogenitas dari suatu data. Dimana untuk menganalisisnya dapat dilihat dari nilai signifikansinya sebesar 0,127 > 0,05, maka dapat dinyatakan data penelitian bersifat homogen. Perhitungan selanjutnya dengan menghitung regresi linier sederhana untuk mengetahui seberapa besar sumbangsih yang diberikan variabel efikasi diri (X) terhadap variabel prestasi belajar (Y) dengan melihat hasil perhitungan koefesien determinasi (R) yang dapat dilihat pada tabel berikut: 
Ermannudin, Pengaruh Efikasi Diri terhadap Prestasi Belajar Siswa Kelas XI IPS pada Mata Pelajaran Ekonomi di SMAN 7 Kerinci

\section{Tabel 7}

Sumbangsih Koefesien Diterminasi

\begin{tabular}{|l|c|r|r|r|}
\hline & & & $\begin{array}{c}\text { Adjusted R } \\
\text { Square }\end{array}$ & $\begin{array}{c}\text { Std. Error of } \\
\text { the Estimate }\end{array}$ \\
\hline 1 & $.423^{\mathrm{a}}$ & .179 & .076 & 3.920 \\
\hline
\end{tabular}

a. Predictors: (Constant), $\mathrm{X}$

Hasil nilai koefesien determinasi bisa dilihat dari niali $\mathrm{R}$ sebesar 0,423 (42,3\%) yang dapat diinterpretasikan jika variabel efikasi diri (X) dapat menerangkan variasi variabel prestasi belajar (Y) pada mata pelajaran ekonomi kelas XI IPS di SMA Negeri 7 Kerinci sebesar 42,3\% dan sisanya diperngaruhi variabel bebas yang lainnya sebesar $57,7 \%$. Untuk melihat adanya pengaruh atau tidak antara variable efikasi diri (X) terhadap prestasi belajar (Y) pada mata ekonomi kelas XI IPS di SMA Negeri 7 Kerinci dapat menggunakan perhitungan dengan uji t yang hasil perhitunganya dapat disajikan pada tabel berikut:

\section{Tabel 8}

\section{Regresi Linier Sederhana dan Uji t}

\begin{tabular}{|c|c|c|c|c|c|c|}
\hline \multicolumn{7}{|c|}{ Coefficients $^{\mathrm{a}}$} \\
\hline \multirow{2}{*}{\multicolumn{2}{|c|}{ Model }} & \multicolumn{2}{|c|}{$\begin{array}{c}\text { Unstandardized } \\
\text { Coefficients }\end{array}$} & \multirow{2}{*}{$\begin{array}{c}\text { Standardized } \\
\text { Coefficients }\end{array}$} & \multirow[b]{2}{*}{$\mathrm{t}$} & \multirow[b]{2}{*}{ Sig. } \\
\hline & & $\mathrm{B}$ & Std. Error & & & \\
\hline 1 & (Constant) & 76.199 & 7.288 & & 10.599 & .000 \\
\hline & $\begin{array}{l}\text { Efikasi } \\
\text { Diri }\end{array}$ & 2.008 & 2.089 & .013 & 2.285 & .034 \\
\hline
\end{tabular}

a. Dependent Variable: Y

Nilai Koefisien $\beta$ adalah suatu bentuk dari persamaan regresi linier sederhana yang diimplementasikan kedalam suatu formula berikut: $\mathrm{Y}=76.199+2.008 \mathrm{X}+\mathrm{e}$. Dari formula tersebut dapat diintepretasikan untuk memahami maksud dan arti dari nilai koefisien konstanta memiliki nilai positif sebesar 76.199, itu artinya ketika efikasi diri (X) tidak memperhatikan prestasi belajar (Y) siswa kelas XI IPS di SMA Negeri 7 Kerinci akan tetap mempunyai prestasi belajar. Sedangkan nilai koefisien efikasi diri bernilai positif sebesar 2.008, artinya setiap kenaikan efikasi diri yang dipunyai siswa kelas XI IPS di SMA Negeri 7 Kerinci meningkat, maka akan disertai juga dengan meningkatnya prestasi belajar siswa. Apabila efikasi diri (X) yang dimiliki siswa kelas XI IPS di SMA Negeri 7 menurun, maka prestasi belajar siswa juga akan menurun.

Dari perhitungan regresi lier sederhana tersebut, terdapat pengujian untuk perhitungan uji t sebagai uji hipotesa dari tujuan penelitian ini. Uji t bertujuan untuk mengetahui pengaruh variabel efikasi diri (X) terhadap prestasi belajar (Y)., dimana nilai t hitung diperoleh variabel efikasi diri sebesar 2,285 dengan taraf signifikansi sebesar 0,034. Nilai t hitung diperoleh sebesar 2,285 > dari t tabel sebesar 2.012, hasil tersebut menginterpretasikan jika variabel efikasi diri (X) memiliki pengaruh positif terhadap prestasi belajar (Y) yang dipunyai siswa kelas XI IPS di SMA Negeri 7 Kerinci. Hasil perhitungan tersebut dapat ditarik suatu hipotesis diterima atau ditolak yaitu dengan melihat nilai t dan taraf nilai signifikansinya. Adapun hipotesis yang diajukan dalam penelitian ini adalah sebagai berikut:

Ho : tidak ada pengaruh efikasi diri (X) terhadap prestasi belajar (Y)

$\mathrm{Ha}$ : ada pengaruh efikasi diri (X) terhadap prestasi belajar (Y)

Penentuan untuk hipotesis dari penelitian ini dapat diterima atau ditolak jika nilai $\mathrm{t}$ hitung $>\mathrm{t}$ tabel dan taraf nilai Sig $<0,05$, maka Ho ditolak. Sedangkan jika nilai t hitung $<\mathrm{t}$ tabel dan taraf nilai Sig $>0,05$, 
Ermannudin, Pengaruh Efikasi Diri terhadap Prestasi Belajar Siswa Kelas XI IPS pada Mata Pelajaran Ekonomi di SMAN 7 Kerinci

maka Ho diterima. Untuk menentukan nilai t tabel, terlebih dahulu menetapkan derajat kebebasan (dk) dengan menggunakan formula keseluruhan sampel yang diteliti $(\mathrm{N})$ dikurangi banyaknya prediktor, sehingga $\mathrm{dk}=\mathrm{n}-1$. Dalam penelitian ini, jumlah prediktor ada 1 yaitu efikasi diri (X) dengan total sampel berjumlah 48 siswa kelas XI IPS SMA Negeri 7 Kerinci, maka $\mathrm{dk}=48-1=47$ pada taraf signifikansi 5\%, maka diperoleh nilai $t$ tabel $=2.012$. Dikarenakan perolehan nilai t hitung variabel efikasi diri $(\mathrm{X})$ sebesar $2,285>\mathrm{t}$ tabel $=2.012$ dan taraf nilai $\mathrm{Sig}=0,034<0,05$, sehingga dapat disimpulkan bahwa Ho ditolak dan Ha diterima artinya ada pengaruh efikasi diri (X) terhadap prestasi belajar (Y) siswa kelas XI IPS SMA Negeri 7 Kerinci. Oleh karena itu efikasi diri (X) siswa kelas XI IPS SMA Negeri 7 Kerinci mempunyai pengaruh terhadap prestasi belajar (Y) secara langsung. Artinya jika efikasi diri (X) siswa kelas XI IPS SMA Negeri 7 Kerinci baik maka prestasi belajar siswa kelas XI IPS SMA Negeri 7 Kerinci juga baik, dan sebaliknya jika efikasi diri (X) siswa kelas XI IPS SMA Negeri 7 Kerinci kurang baik maka prestasi belajar siswa kelas XI IPS SMA Negeri 7 Kerinci juga tidak baik.

Efikasi akan mampu mendorong siswa memiliki motivasi belajar, mencoba dan mengerjakan tugas yang diberikan padanya, mempunyai kepercayaan diri bisa mengerjakan tugas walaupun tugas tersebut sulit tetap tertantang untuk menyelesaikanya sesuai dengan apa yang diharapkan. Keyakinan diri yang dimiliki siswa tinggi akan membawa siswa tersebut merasa puas akan kemampuan yang dimiliki. Hal tersebut sejalan dengan teori efikasi diri menurut Bandura (1997) yang menyatakan bahwa Self efficacy beliefs determine how people feel, think, motivate themself and behave. Dapat dikatakan bahwa efikasi diri berupa keyakinan siswa bahwa dirinya memiliki kemampuan dalam melaksanakan sesuatu tugas untuk mencapai keberhasilan. Dengan demikian dapat dikatakan bahwa bagi siswa yang memiliki efikasi diri tinggi maka prestasi belajarnya juga tinggi.

Hasil penelitian ini juga sependapat dengan hasil penelitian Monika dan Adman (2017) yaitu variabel efikasi diri berpengaruh positif terhadap hasil belajar siswa pada mata pelajaran produktif program keahlian administrasi perkantoran. Siswa yang mempunyai efikasi dirri yang tinggi akan mempunyai permorma yang lebih baik dari siswa yang mempunyai efikasi diri rendah. Hal tersebut mengindikasikan bahwa siswa memilki keyakinan diri yang tinggi akan mempengaruhi prestasi belajar siswa juga akan tinggi, dikarenakan efikasi diri memunculkan keyakinan diri dan kemampuan dalam mengerjakan segala tugas yang diberikan walaupun tugas tersebut sulit, tetapi bagi siswa yang mempunyai efikasi diri yang tinggi akan tetap bisa menyelesaikanya dengan baik sesuai dengan apa yang diharapkan. Sedangkan hasil penelitian ini berbeda dengan hasil yang dilakukan Azwar (2012) yaitu efikasi diri tidak memiliki pengaruh yang signifikan terhadap prestasi belajar, sekaligus oenelitianya menolak teori Bandura. Menurut Azwar (2012) efikasi diri dipandang sebagai persepsi subjektif tanpa adanya dasar yang jelas untuk penghayatan akan pengalaman masa lampau dan pengarahan diri sehingga ditentukan ekspektasi yang maya. Sehingga akhirnya dampak korelasi efikasi diri yang persepsikan dan prestasi belajar tidak terlihat.

\section{SIMPULAN}

Hasil penelitian dan pembahasan yang telah dipaparkan sebelumnya dapat ditarik suatu kesimpulan bahwa terdapat pengaruh positif efikasi diri terhadap prestasi belajar siswa pada mata pelajaran ekonomi kelas XI IPS SMA Negeri 7 Kerinci. Hal ini dibuktikan dari uji hipotesis dengan menggunakan uji t dengan taraf signifikansi 0,05. Dimana, nilai $t$ hitung $>t$ tabel dan siginifikansi 0,034 $<0,05$. Pengaruh efikasi diri terhadap prestasi belajar tergolong cukup kuat yaitu sebesar $42,3 \%$ dan sisanya diperngaruhi variabel bebas yang lainnya sebesar 57,7\%. Hasil tersebut menunjukan bahwa semakin tinggi efikasi diri yang dipunyai siswa akan membawa pengaruh yang tinggi juga prestasi belajar siswa pada mata pelajaran ekonomi dan sebaliknya apabila efikasi diri yang dipunyai siswa rendah maka akan membawa pengaruh yang rendah juga prestasi belajar pada mata pelajaran ekonomi.

\section{DAFTAR PUSTAKA}

Arifin, Zainal. 2011. Penelitian Pendidikan. Bandung: Remaja Rosda

Arikunto,Suharsimi.2017.Dasar-Dasar Evaluasi Pendidikan Edisi 2.Jakarta : PT Bumi Aksara 
Ermannudin, Pengaruh Efikasi Diri terhadap Prestasi Belajar Siswa Kelas XI IPS pada Mata Pelajaran Ekonomi di SMAN 7 Kerinci

Artha, W. I., \& Supriyadi. 2013. Hubungan Antara Kecerdasan Emosi dan Self Efficacy dalam Pemecahan Masalah Penyesuaian Diri Remaja Awal. Psikologi Udayana, I(1), 190-202.

Azwar. 2012. Penyusunan Skala Psikologi. Yogyakarta: Pustaka Pelajar

Bandura, A. 1997. Self Efficacy - The Exercise of Control (Fifth Printing, 2002). New York: W.H. Freeman \& Company

Depdiknas .2003. Undang-undang RI No.20 tahun 2003.tentang sistem pendidikan nasional

Djamarah, Syaiful Bahri. 2012. Psikologi Belajar. Jakarta : Rineka Cipta.

Fathhulkhoir, A.S. 2015. Pengaruh Penggunaan Model Pembelajaran Kooperatif Tipe Group Investigation (GI) terhadap Kemampuan Pemecahan Masalah Siswa Kelas XI pada Materi Koloid Di SMA Negeri 2 Bantul Yogyakarta. Skripsi UIN Sunan Kalijaga. Tidak Diterbitkan

Feist, J. \& Gregory J. Feist. 2009. Theories of Personality (Edisi Keenam). Yogyakarta: Pustaka Pelajar.

Friedman, Howard S. \& Schustack, Miriam W. 2006. Kepribadian Teori Klasik dan Riset Modern Edisi Ketiga Terjemahan. Jakarta: Penerbit Erlangga.

Ghufron \& Risnawita. 2011. Teori-Teori Psikologi. Yogyakarta: Ar-Ruzz Madia

Ghozali, Imam. 2018. Aplikasi Analisis Multivariate dengan Program IBM SPSS 25. Semarang: Badan Penerbit Universitas Diponegoro

Hidayat, Dede Rahmat. 2015. Psikologi Kepribadian Dalam Konseling. Bogor: Grafika Telindo Press Ihsana, 2017. Belajar dan Pembelajaran. Yogyakarta: Pustaka Pelajar.

Istirani, dan Intan Pulungan.2017.Enslikopedia Pendidikan Jilid I. Medan: Media Persada

Kagan, S. 1994. Cooperative Learning. San Clemente, CA: Kagan Cooperative Learning.

Maesaroh, Siti. 2013. Peranan Metode Pembelajaran Terhadap Minat Dan Prestasi Belajar Pendidikan Agama Islam. Jurnal Kependidikan. Vol. 1 No. 1 November 2013. Diakses pada 20 Maret 2018 dari https://media.neliti.com/media/publications/

Mawanti, Dwi. 2011. Studi Efikasi Diri Mahasiswa yang bekerja Saat penyusunan Skripsi. Semarang: Fakultas Tarbiyah

Monika dan Adman. 2017. Peran efikasi diri dan motivasi belajar dalam meningkatkan hasil belajar siswa sekolah menengah kejuruan. Jurnal Pendidikan Manajemen Perkantoran Vol. 2 No. 2, Juli 2017, Hal. 219-226

Ormrod, Jeanne Ellis. 2008. Psikologi Pendidikan Membantu Siswa Tumbuh Dan Berkembang Jilid 2 Edisi Terjemah. Jakarta: Erlangga,

Pinasti, Woro. 2011. Pengaruh Self-Efficacy, Locus Of Control, dan Faktor Demografis Terhadap Kematangan Karir Mahasiswa. UIN Syarif Hidayatullah Jakarta.

Pratiwi,Noor Komari. 2015. Pengaruh Tingkat Pendidikan, Perhatian Orang Tua, dan Minat Belajar Siswa Terhadap Prestasi Belajar Bahasa Indonesia Siswa SMK Kesehatan Di Kota Tangerang. Jurnal Pujangga Volume 1, Nomor 2, Desember

Riduwan. 2012. Belajar Mudah Penelitian untuk Guru, Karyawan dan Peneliti Pemula. Bandung: ALFABETA.

Rosyid, Moh Zaiful, Mustajab, Aminol. 2019. Prestasi Belajar. Malang: CV Literasi Nusantara Abadi.

Slameto. 2015. Belajar dan Faktor-faktor yang Memengaruhinya. Jakarta: Rineka Cipta

Smith, Mark K et.al (2010). Learning and Teaching Theory: Measuring Your Success in Teaching and Learning with the World's Educational Psychologists. Jogjakara: Mirza Media Pustaka

Susanti, Lidia. 2019. Prestasi Belajar Akademik dan Non Akademik Teori dan Implementasinya. Jakarta: Bumi Aksara

Syah, Muhibbin. 2017. Psikologi Pendidikan dengan Pendekatan Baru. Bandung: PT. Remaja Rosdakarya 
Ermannudin, Pengaruh Efikasi Diri terhadap Prestasi Belajar Siswa Kelas XI IPS pada Mata Pelajaran Ekonomi di SMAN 7 Kerinci 